\title{
Brazilian researchers took first bite at 'new muscle'
}

São Paulo. A group of Brazilian researchers has been taken aback by the announcement by US dentists of the discovery of a new facial muscle, because they described it themselves in a local journal in 1978.

Gary Hack, assistant professor of dentistry at the University of Maryland in Baltimore, and Gwendolyn Dunn, an orthodontist, say they discovered the muscle, involved with mastication, because they opted for an unusual way of dissecting the face, carving not from the traditional direction, from the side of the head, but from the front (see Nature Medicine 2, 506; 1996).

The 'undiscovered' muscle was found to run from behind the eye socket to the lower jaw. Hack and Dunn went on to dissect other heads and to scan the scientific literature to find whether the muscle had already been described. They waited a year before making their announcement. "We reviewed 15 textbooks," says Hack, without finding the muscle.

The Americans called the muscle sphenomandibularis, as it begins at the sphenoid and has an insertion point at the mandible. If correct, this would be the fifth muscle involved with mastication. But when the announcement was reported by the media, it came to the attention of Luis Roberto de Toledo Ramalho, a Brazilian researcher at the Faculty of Dentistry at UNESP (São Paulo State University) at Araraquara.

Toledo immediately remembered an earlier research paper written with two colleagues, Carlos Landucci and Helio Ferraz Porciuncula, which was published in the Revista da Faculdade de Odontologia, the faculty's own journal. The journal is published in Portuguese and does not have a wide circulation.

Considering it unlikely that centuries of dissection would have let pass such a thing, the Brazilians had not thought that they were dealing with a new muscle, and they labelled it merely "deep portion of the temporal human muscle". Toledo sent a copy of his work, together with colour photographs, to Hack. "I am not interested in any sort of polemics," says Toledo, "I just want to show that we had already done work on this, and we do not believe it is a new muscle."

"We were fascinated," says Hack. "Their description goes beyond anything we have seen in any textbook. I wish we had known this work before. But we disagree about the conclusion. We are finding some very interesting data, including biochemical and physiological analysis, that shows it is a different muscle."

Whether or not Hack proves that the "deep portion" deserves to be called sphenomandibularis, Brazilian scientists are sensitive to the fact that relevant research was buried in an obscure Portugueselanguage journal. "I wonder what else could be hidden in these kind of journals," says Toledo.

Ricardo Bonalume Neto

\section{Cash and contacts are keys in the East}

Munich. Basic science in the former communist countries of central and eastern Europe is hampered not just by an acute lack of money, but also by the difficulties of maintaining contacts between scientists, according to participants in a workshop in Paris last week, which drew together representatives from research organizations in 14 countries.

The workshop was sponsored by the International Council of Scientific Unions (ICSU), the European Union, the European Science Foundation, and INTAS, the European funding agency for scientists in eastern Europe.

The percentage of gross domestic product allocated to research has fallen dramatically in all the former Communist countries in the last few years, in some cases to only one-tenth of its 1989 value. In many countries new laws stipulate an increase in funding. But, said delegates, these are systematically ignored by governments facing more urgent needs. What little money there is tends to be directed to applied research.

Communication between the new research agencies in such countries has also suffered since the fall of communism. The plethora of new agencies, with diverse responsibilities, is confusing to western research organizations, making international collaboration difficult. The workshop recommended the setting up of a home page on the World Wide Web to list and describe all such agencies in the West and the East.

The workshop asked for international support to help sift through the wealth of unpublished material in the archives of research institutes - particularly in the former Soviet Union - that were closed to the outside world during the communist era. It also asked for international support to promote the sharing of large research facilities among eastern European countries.

Alison Abbott

\section{Outbreak of $E$. coli infection in Japan renews concerns}

Tokyo. Concern was sparked among public health officials around the world last week when more than 6,000 schoolchildren in Sakai, Osaka city, were struck down with infection by the 0157 strain of the bacterium Escherichia coli.

The strain was first linked with illness in humans in the United States in 1982, when it caused severe diarrhoea in individuals who had eaten contaminated hamburgers at a national fast-food chain.

The outbreak in Sakai follows smaller outbreaks in schools around Japan. These began in May in Okayama Prefecture, west of Osaka, where two children died of complications caused by a toxin released by the bacteria.

More than 600 of the children in Sakai have been in hospital and two are in a critical condition with cerebral bleeding and kidney failure. Another 75 have developed haemolytic uraemic syndrome (HUS), which is characterized by haemolytic anaemia and kidney failure.

Non-toxic strains of $E$. coli occur naturally in animals, including humans, helping to suppress the growth of harmful bacteria and synthesizing vitamins. The 0157 strain, which is carried by some cattle, is a rare variety that produces potent toxins.

Unlike other forms of food poisoning, where millions of bacteria have to infect a person to cause symptoms, it is suspected that, as in the case of dysentery, ingestion of as few as ten bacteria can cause disease. So secondary infections passed on via the stools of infected individuals are common. Children and the elderly are particularly susceptible to infection.

School lunches are thought to be involved in the current outbreak in Japan, although the source has been pinned down precisely in only one case; a young boy in Yokohama, near Tokyo, ate raw beef liver subsequently found to be contaminated with the bacteria. But preliminary DNA studies of bacteria from the various outbreaks, carried out by the National Children's Hospital and the National Institute of Health in Tokyo, suggest multiple sources for the outbreaks.

The Ministry of Health and Welfare is coming under severe criticism from health experts for not taking more stringent measures to contain the disease. The ministry has so far treated it as food poisoning rather than as an infectious disease. But many health experts argue that, because of the contagious nature of the bacteria and the common occurrence of secondary infections, the outbreaks should be covered by the Infectious Diseases Prevention Law. That would require quarantine and disinfection measures.

David Swinbanks 